\title{
In situ identification of nocardioform actinomycetes in activated sludge using fluorescent rRNA-targeted oligonucleotide probes
}

\author{
Markus Schuppler, ${ }^{1} \dagger$ Michael Wagner, ${ }^{2}$ Georg Schön ${ }^{3}$ and Ulf B. Göbel' $¥$
}

Author for correspondence: Markus Schuppler. Tel: +49351463 8591. Fax: +493514638573.

e-mail: ms43@irz.inf.tu-dresden.de

1 Institut für Medizinische Mikrobiologie und Hygiene, Klinikum der Albert-Ludwigs-Universităt Freiburg, Hermann-HerderStraße 11, D-79104

Freiburg, Germany

2 Lehrstuhl für Mikrobiologie, Technische Universităt München, Arcisstraße 16, D-80290 München, Germany

3 Institut für Mikrobiologie der Fakultăt für Biologie II, Albert-Ludwigs-Universität Freiburg, Schănzlestraße 1, D-79104 Freiburg, Germany

\begin{abstract}
Hitherto, few environmental samples have been investigated by a 'full cycle rRNA analysis'. Here the results of in situ hybridization experiments with specific rRNA-targeted oligonucleotide probes developed on the basis of new sequences derived from a previously described comparative 165 rRNA analysis of nocardioform actinomycetes in activated sludge are reported. Application of the specific probes enabled identification and discrimination of the distinct populations of nocardioform actinomycetes in activated sludge. One of the specific probes (DLP) detected rod-shaped bacteria which were found in 13 of the 16 investigated sludge samples from various wastewater treatment plants, suggesting their importance in the wastewater treatment process. Another probe (GLP2) hybridized with typically branched filaments of nocardioforms mainly found in samples from enhanced biological phosphorus removal plants, suggesting that these bacteria are involved in sludge foaming. The combination of in situ hybridization with fluorescently labelled rRNA-targeted oligonucleotide probes and confocal laser scanning microscopy improved the detection of nocardioform actinomycetes, which often showed only weak signals inside the activated-sludge flocs.
\end{abstract}

Keywords: fluorescence in situ hybridization, 16S rRNA, activated sludge, nocardioform actinomycetes, confocal laser scanning microscopy

\section{INTRODUCTION}

Foaming of activated sludge due to an extensive multiplication of filamentous bacteria causes serious separation problems in sewage treatment plants throughout the world (Lemmer \& Kroppenstedt, 1984; Blackbeard et al., 1986; Blackall et al., 1991). In addition to Microthrix parvicella, a filamentous bacterium belonging to the group of high G + C Gram-positive bacteria (Blackall et al., 1994a), branched, filamentous members of the genera Gordona, Nocardia and Rhodococcus are

\footnotetext{
†Present address: Institut fur Medizinische Mikrobiologie und Hygiene, Universitatsklinikum Carl Gustav Carus, Technische Universitat Dresden, Dürerstraße 24, D-01307 Dresden, Germany.

‡Present address: Institut für Medizinische Mikrobiologie und Hygiene, Medizinische Fakultăt (Charité), Humboldt-Universităt Berlin, Dorotheenstraße 96, D-10098 Berlin, Germany.

Abbreviations: CLSM, confocal laser scanning microscopy; EBPR, enhanced biological phosphorus removal; FISH, fluorescence in situ hybridization.
}

generally considered to be the cause of foaming in sewage treatment plants (Lechevalier \& Lechevalier, 1974; Lechevalier et al., 1976; Blackbeard et al., 1986; Blackall et al., 1988). The reasons for the extensive multiplication of these filamentous bacteria are still unknown (Soddell \& Seviour, 1990). Fast and reliable cultivation-independent identification techniques for filamentous bacteria in activated sludge are a prerequisite for the evaluation of their importance in the sewage treatment process and investigation of the problems that can arise. Classical approaches fail to differentiate foamcausing species such as Gordona amarae, Rhodococcus rhodochrous and Tsukamurella paurometabolum due to their variable morphology, staining behaviour and fastidious nature (Foot et al., 1992).

Comparative sequence analysis of $16 \mathrm{~S}$ rRNA sequences directly retrieved from natural microbial communities represents the most powerful method for describing species composition as both cultured and as yet uncultured micro-organisms can be identified. Sequence 
Table 1. Whole-cell hybridization of reference strains with rRNA probes applied to ethanol-fixed cultures after mutanolysin treatment

\begin{tabular}{|c|c|c|c|c|}
\hline \multirow[t]{2}{*}{ Species } & \multirow[t]{2}{*}{ Source* } & \multicolumn{3}{|c|}{ Hybridization with probet: } \\
\hline & & EUB338 & HGC69a & MNP1 \\
\hline Acinetobacter sp. BR-2 & MIBI & + & - & - \\
\hline Corynebacterium variabilis & DSM 20536 & + & + & + \\
\hline Dietzia maris & DSM $43672^{\mathrm{T}}$ & + & + & + \\
\hline Escherichia coli & ATCC 25922 & + & - & - \\
\hline Gordona amarae & DSM $43392^{\mathrm{T}}$ & $+1-$ & $+1-$ & $+1-$ \\
\hline Gordona rubropertincta & DSM $43197^{\mathrm{T}}$ & $+1-$ & $+1-$ & $+1-$ \\
\hline Gordona rubropertincta & DSM 43248 & + & + & + \\
\hline Gordona sputi & DSM 44019 & $+1-$ & $+1-$ & $+1-$ \\
\hline Gordona terrae & DSM $43249^{\mathrm{T}}$ & $+1-$ & $+1-$ & $+1-$ \\
\hline Mycobacterium fortuitum & IMMH & - & - & - \\
\hline Mycobacterium gordonae & $\mathrm{IMMH}$ & - & - & - \\
\hline Nocardia asteroides & IMMH & $+1-$ & $+1-$ & $+1-$ \\
\hline Rhodococcus equi & ITH & + & + & + \\
\hline Rhodococcus erytbropolis & DSM $43066^{T}$ & $+1-$ & $+1-$ & $+1-$ \\
\hline Rhodococcus erythropolis & DSM $43135^{\mathrm{T}}$ & + & + & + \\
\hline Rhodococcus erythropolis FM1 & MIBI & + & + & + \\
\hline Rhodococcus fascians & DSM 20669 & $+1-$ & $+1-$ & - \\
\hline Rhodococcus globerulus & DSM 43954 ${ }^{\mathrm{T}}$ & + & + & + \\
\hline Rhodococcus luteus & DSM $43673^{\mathrm{T}}$ & + & + & + \\
\hline Rhodococcus marinonascens & DSM $43752^{\mathrm{T}}$ & + & + & + \\
\hline Rhodococcus rhodnii & DSM $43336^{\mathrm{T}}$ & $+1-$ & $+1-$ & $+1-$ \\
\hline Rhodococcus rhodochrous & DSM $43241^{\mathrm{T}}$ & + & + & + \\
\hline Rhodococcus ruber & DSM 43338 & + & + & + \\
\hline Rhodococcus sp. & DSM 427 & + & + & + \\
\hline Tsukamurella paurometabolum & DSM 43246 & $+1-$ & $+1-$ & - \\
\hline Tsukamurella paurometabolum & DSM 43274 & $+1-$ & $+1-$ & - \\
\hline
\end{tabular}

* T, Type strain; ATCC, American Type Culture Collection, Rockville, MD, USA; DSM, Deutsche Sammlung von Mikroorganismen und Zellkulturen, Braunschweig, Germany; IMMH, Institut für Medizinische Mikrobiologie und Hygiene, Freiburg, Germany; ITH, Institut für Tierhygiene, Freiburg, Germany; MIBI, Mikrobiologisches Institut der Fakultät für Biologie II, Freiburg, Germany.

$\dagger+$, Bright signal; - , no signal; $+/-$, partial signal.

information can be used to design rRNA-targeted oligonucleotide probes which enable quantification and analysis of the spatial distribution of these microorganisms in ecosystems by fluorescence in situ hybridization (FISH) (Amann et al., 1995).

While whole-cell hybridization of Gram-negative bacteria works well, in situ hybridization of some groups of Gram-positive bacteria remains rather difficult. The members of the nocardioform genera Corynebacterium, Dietzia, Gordona, Mycobacterium, Nocardia, Rbodococcus and Tsukamurella possess rigid cell envelopes containing mycolic acids with very long aliphatic chains. Consequently, the cell walls of these bacteria are much more difficult to permeabilize, so that probe targets are not accessible to fluorescently labelled oligonucleotide probes. Therefore, methods such as short-time paraformaldehyde fixation (De Los Reyes et al., 1997), enzymic digestion (Hahn et al., 1992) and mild acid hydrolysis (Macnaughton et al., 1994) have been applied to optimize permeabilization of bacteria with mycolic- acid-containing cell walls for fluorescent oligonucleotide probes.

In an earlier study (Schuppler et al., 1995), a molecular approach (Olsen et al., 1986) was used to retrieve new 16S rRNA sequences from nocardioform actinomycetes present in an activated-sludge sample. Based on these sequences, we developed and here describe the use of a set of fluorescently labelled rRNA-targeted oligonucleotide probes to study the presence and abundance of the respective target bacteria in activated sludge from various sewage treatment plants.

\section{METHODS}

Bacterial strains and culture conditions. The strains used in this study are listed in Table 1. Bacteria were cultured as described in the catalogue of strains from the DSM (Deutsche Sammlung von Mikroorganismen und Zellkulturen, Braunschweig, Germany). Nocardioform actinomycetes were cultured in modified Czapek-Dox media (Lechevalier, 1989). Cells were harvested at late exponential phase by centrifu- 
Table 2. In situ identification of nocardioform actinomycetes in activated sludge from sewage treatment plants in Germany

+ , Probe target population detectable; - , probe target population not detectable.

\begin{tabular}{|lcccccc|}
\hline Sewage & \multicolumn{7}{c|}{ Hybridization with probe: } \\
\cline { 2 - 7 } treatment plant & MNP1 & MLP & DLP & GLP1 & GLP2 & GLP3 \\
\hline Aldersbach & + & - & + & - & - & - \\
Aretsried & + & - & + & - & + & - \\
Breisach & - & - & - & - & - & - \\
Darmstadt* & + & - & - & - & + & - \\
Dietersheim & + & - & + & - & - & - \\
Essen-Werden & + & - & + & - & - & - \\
Großlappen & + & - & + & - & - & - \\
Hattingen & + & - & + & - & - & - \\
Hirblingen* & + & - & + & - & - & - \\
Kraftisried & - & - & - & - & - & - \\
Marienfelde* & + & - & + & - & + & - \\
Moosbach & + & - & + & - & - & - \\
Schönerlinde & + & - & + & - & - & - \\
Stahnsdorf & + & - & + & - & - & - \\
Waßmannsdorf* & + & - & + & - & + & - \\
Wyk & + & - & + & - & - & - \\
\hline
\end{tabular}

* EBPR plant.

Table 3. Probe sequences, target sites, hybridization temperature for dot-blot hybridization, and formamide concentration in the hybridization buffer required for specific in situ hybridization

\begin{tabular}{|c|c|c|c|c|}
\hline Probe & Sequence $\left(5^{\prime}-3^{\prime}\right)$ & Target site & $\begin{array}{c}\text { Hybridization } \\
\text { temp. }\left({ }^{\circ} \mathrm{C}\right)\end{array}$ & $\begin{array}{r}\text { Formamide } \\
\text { concn }(\%)\end{array}$ \\
\hline HGC69a† & TATAGTTACCTCCGCCGT & 23S, 1901-1918 & NU & 25 \\
\hline EUB338 & GCTGCCTCCCGTAGGAGT & $16 \mathrm{~S}, 338-355$ & 54 & 15 \\
\hline MNP15 & TTAGACCCAGTTTCCCAGGCT & $16 S, 152-172$ & 55 & 50 \\
\hline MLP $\|$ & AACCCATGCAGGCCGTAGTCC & $16 S, 182-202$ & 62 & ND \\
\hline DLP $\|$ & CCACCATGCGGCAGGAGCTCA & $16 \mathrm{~S}, 182-202$ & 70 & 40 \\
\hline GLP1\| & ATGCAGTGGAAGGTAATATC & $16 S, 174-193$ & 50 & ND \\
\hline GLP2\| & AAGGGCAGGTCATATCCGGT & $16 S, 178-197$ & 58 & 45 \\
\hline GLP3\| & CCAACCATGCAGTCAGAGGTC & $16 S, 182-202$ & 58 & ND \\
\hline
\end{tabular}

NU, Not used for dot-blot hybridization; ND, formamide concentrations were not determined for probes MLP, GLP1 and GLP3 as these probes could not be used for FISH.

*rRNA position, E. coli numbering (Brosius et al., 1981).

†Roller et al. (1994).

‡Stahl \& Amann (1991).

SSchuppler et al. (1995).

|| Derived from sequences of Schuppler et al. (1995) (see Fig. 1).

gation $(2 \mathrm{~min}, 5000 \mathrm{~g}$ ) and washed in PBS $(130 \mathrm{mM} \mathrm{NaCl}$,

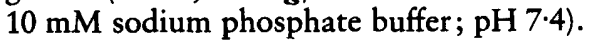

Cell fixation and pre-treatment. Activated-sludge samples were collected from the aeration basins of sewage treatment plants (Table 2) and fixed immediately by addition of ethanol to a final concentration of $50 \%(\mathrm{v} / \mathrm{v})$. In the laboratory, the activated sludge was centrifuged $(2 \mathrm{~min}, 5000 \mathrm{~g})$ and resuspended in PBS/ethanol $(1: 1, \mathrm{v} / \mathrm{v})$. Gram-positive reference strains were fixed in PBS/ethanol $(1: 1, \mathrm{v} / \mathrm{v})$ (Roller et al., 1994), whereas Gram-negative reference strains were fixed in paraformaldehyde $(4 \%, w / v$, in PBS) and processed as described by Amann et al. (1990a). After dehydration, immobilized nocardioform bacteria and activated-sludge samples were pre-treated by adding $10 \mu \mathrm{l}$ enzyme solution [5000 U mutanolysin $\mathrm{ml}^{-1}$ from Streptomyces globisporus (Sigma) in $0 \cdot 1 \mathrm{M}$ potassium phosphate buffer, $\mathrm{pH} 6 \cdot 2$ ] and 


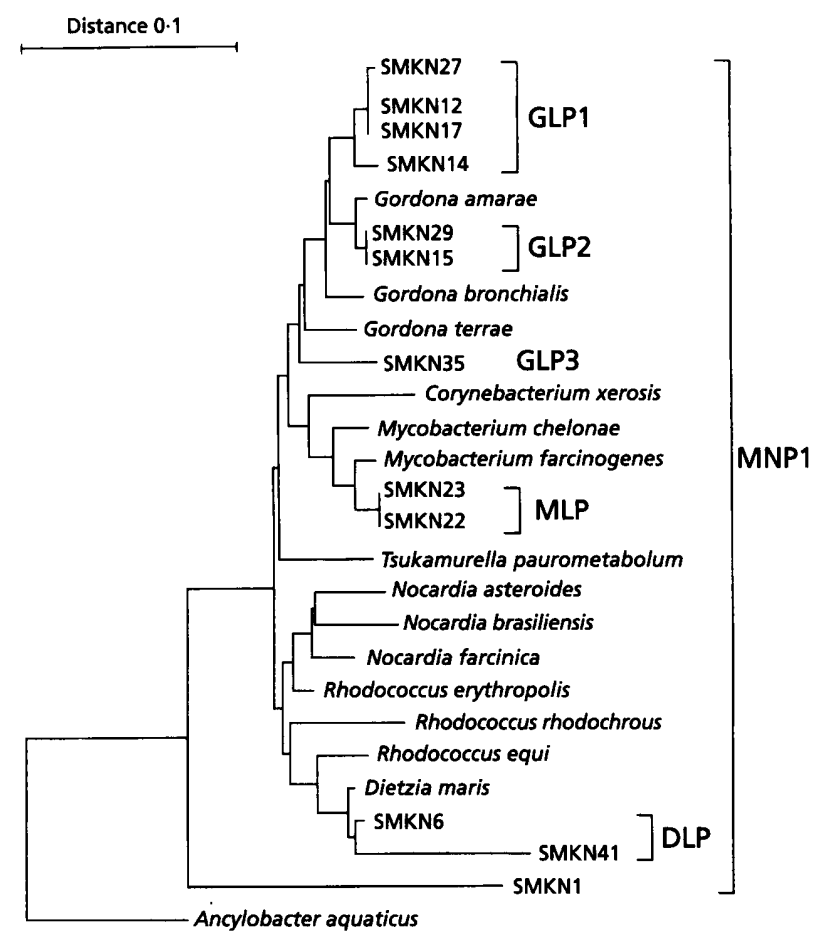

Fig. 1. Specificity of probes MNP1, MLP, DLP, GLP1, GLP2 and GLP3. The dendrogram is based on partial 16S rRNA gene sequences and indicates the phylogenetic relationships among selected Gram-positive bacteria and the clone sequences (SMKN) from a former 165 rRNA sequence analysis of an activated-sludge sample (Schuppler et al., 1995). The scale-bar represents $10 \%$ difference in nucleotide sequence.

incubating for $10 \mathrm{~min}$ at room temperature. To remove the mutanolysin solution, slides were rinsed with distilled water, air-dried and dehydrated again. Lysozyme treatment was performed according to the protocol of Beimfohr et al. (1993).

165 rRNA sequence analysis. Sequence analysis and construction of dendrograms was done as previously described by Schuppler et al. (1995).

Oligonucleotide probes. Sequences and the target sites of the oligonucleotide probes used in this study are presented in Table 3. Oligonucleotide probes MLP, DLP, GLP1, GLP2 and GLP3 (Fig. 1) were derived from 16S rRNA sequences described by Schuppler et al. (1995). Probes were synthesized with a C6-TFA-aminolinker [6-(trifluoroacetylamino)-hexy](2-cyanoethyl)-( $N, N$-diisopropyl)phosphoramidite; Millipore] at the $5^{\prime}$-end. Labelling of the probes with tetramethylrhodamine-5-isothiocyanate (Molecular Probes) or 5(6)-carboxyfluorescein- $N$-hydroxysuccinimide ester (Boehringer Mannheim), and purification of the oligonucleotide-dye conjugates were performed as described by Amann $e t$ al. (1990a). Oligonucleotide probes for dot-blot hybridization were labelled with digoxigenin (DIG oligonucleotide $3^{\prime}$-end labelling kit; Boehringer Mannheim) according to the manufacturer's instructions.

Nucleic acid extraction and dot-blot hybridization. Plasmid DNA preparations of recombinant Escherichia coli clones (Schuppler et al., 1995) were dotted on positively charged nylon membranes (Biodyne $\mathrm{B}$; Pall) and immobilized by baking for $2 \mathrm{~h}$ at $80^{\circ} \mathrm{C}$. Hybridization with digoxigenin- labelled oligonucleotide probes was done in hybridization tubes (Bachofer). Membranes were pre-hybridized for $1 \mathrm{~h}$ at $50^{\circ} \mathrm{C}$ in $20 \mathrm{ml}$ hybridization buffer without oligonucleotide probe $[5 \times \mathrm{SSC}, 2 \%(\mathrm{w} / \mathrm{v})$ blocking reagent (Boehringer Mannheim), $0 \cdot 1 \%(\mathrm{w} / \mathrm{v}) \quad N$-lauroylsarcosine, $0 \cdot 2 \%(\mathrm{w} / \mathrm{v})$ SDS] followed by hybridization with $3 \mathrm{ml}$ hybridization buffer containing $50 \mathrm{pmol}$ labelled oligonucleotide probe for $2 \mathrm{~h}$ at the appropriate temperature for each probe. After hybridization, the membranes were washed twice in $20 \mathrm{ml}$ washing buffer [ $5 \times \mathrm{SSC}, 0.2 \%(\mathrm{w} / \mathrm{v}) \mathrm{SDS}$ ] for $15 \mathrm{~min}$ at the hybridization temperature. Detection was carried out using anti-DIG antibodies coupled with alkaline phosphatase (DIG Luminescent Detection kit; Boehringer Mannheim) as indicated by the manufacturer. Chemiluminescence was detected by exposure of membranes to X-ray films (Kodak X-Omat AR). Prior to rehybridization, the membranes were stripped by pouring boiling $0.1 \times$ SSC, $0.2 \%(\mathrm{w} / \mathrm{v})$ SDS over the membranes followed by incubation until the buffer reached room temperature.

In situ hybridization. In situ hybridization of fixed materials was carried out at a constant temperature of $46^{\circ} \mathrm{C}$ in an isotonically equilibrated humidity chamber according to the method of Amann et al. (1990a). On each well of the microscope slide, $8 \mu \mathrm{l}$ hybridization buffer $(0.9 \mathrm{M} \mathrm{NaCl}$; $0.02 \mathrm{M}$ Tris $/ \mathrm{HCl}, \mathrm{pH} 7 \cdot 2 ; 0.01 \%, \mathrm{w} / \mathrm{v}, \mathrm{SDS})$ and $50 \mathrm{ng}$ probe were applied and incubated for $2-4 \mathrm{~h}$. Stringent hybridization conditions for the different oligonucleotide probes were adjusted by different formamide concentrations in the hybridization buffer as described by Manz et al. (1992).

Microscopy and documentation. Slides were examined using a Leitz DMRB microscope (Leica) with filter sets I3 and N2.1. Colour photomicrographs were prepared with Fuji P 1600 colour reversal film. Exposure times were 0.01-0.03 s for phase-contrast photomicrographs and $15-25 \mathrm{~s}$ for epifluorescence photomicrographs.

Confocal laser scanning microscopy (CLSM) was done on a Carl Zeiss LSM 410 equipped with an Ar-ion laser (488 nm) and a $\mathrm{HeNe}$ laser $(543 \mathrm{~nm})$ by recording optical sections. Image processing, depth profiles and three-dimensional reconstructions were performed with the standard software package delivered with the device.

\section{RESULTS}

\section{Comparison of different fixation and pre-treatment procedures for permeabilization of nocardioform actinomycetes for whole-cell hybridization}

Fixation and hybridization conditions normally used for in situ hybridization of Gram-negative bacteria are often unsuitable for Gram-positive bacteria (Roller et al., 1994). This effect can be easily visualized by in situ hybridization of a paraformaldehyde-fixed mixed culture of Acinetobacter sp. and Rhodococcus erythropolis FM1 cells with the eubacteria-specific oligonucleotide probe EUB338. While the Gram-negative Acinetobacter sp. cells are intensively stained, the cells of the Grampositive species $R$. erythropolis give poor and nonhomogeneous fluorescence signals (Fig. 2a).

To improve the hybridization efficiency of mycolic-acidcontaining nocardioform actinomycetes, we tested the influence of different fixation protocols on cell wall permeability to fluorescently labelled oligonucleotide 

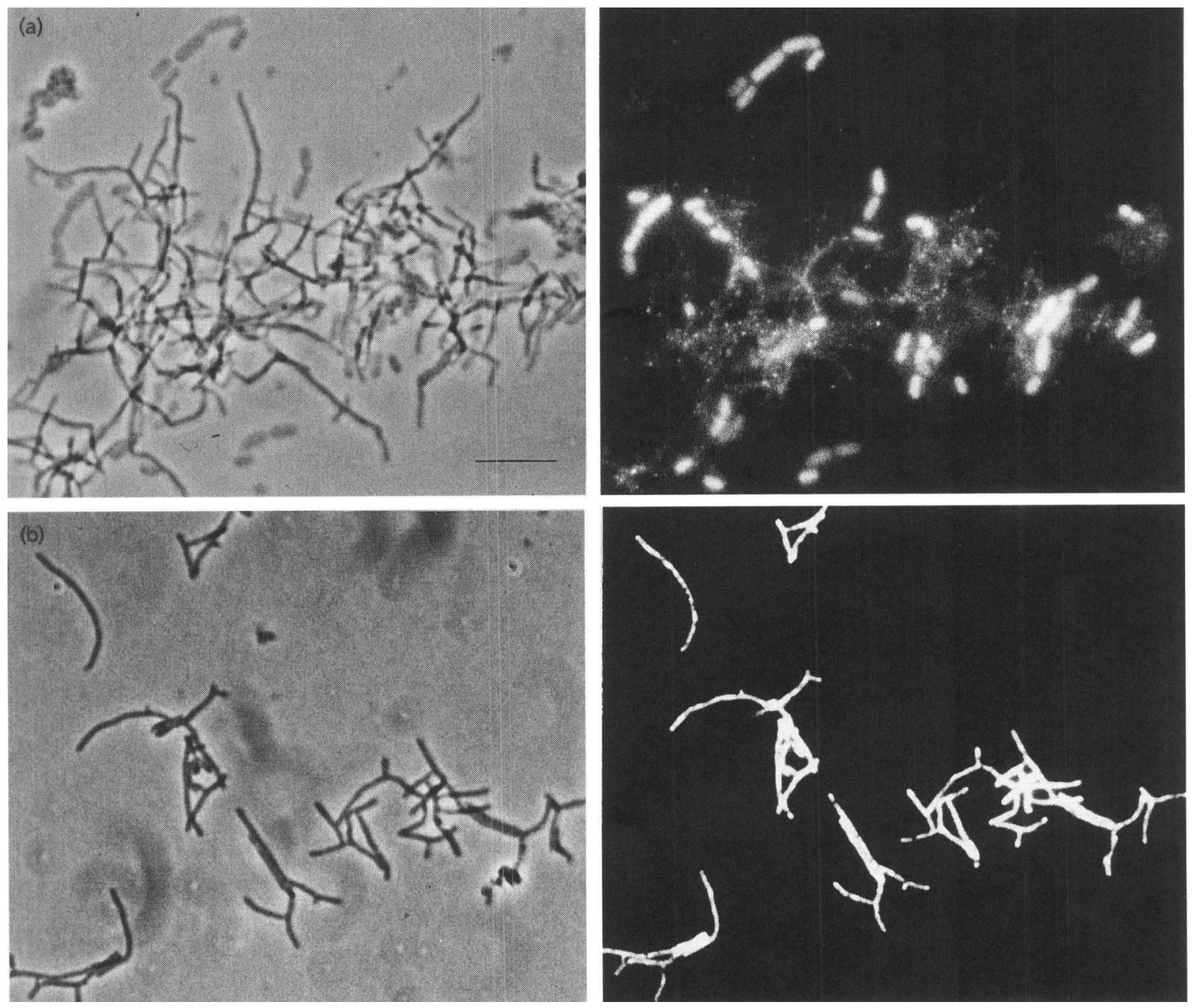

Fig. 2. Fixation and pre-treatment of nocardioform actinomycetes for FISH. For each panel, identical fields were viewed by phase-contrast microscopy (left) and epifluorescence microscopy (right). Bar, $10 \mu \mathrm{m}$. (a) Whole-cell hybridization of an artificial mixture of paraformaldehyde-fixed Acinetobacter Sp. BR-2 and $R$. erythropolis FM1 with fluorescein-labelled probe EUB338. (b) In situ hybridization of a pure culture of ethanol/PBS-fixed and mutanolysin-treated $R$. erythropolis FM1 with tetramethylrhodamine-labelled probe MNP1.

probes. For most of the members of the nocardioform actinomycetes analysed, cell fixation with ethanol/PBS $(1: 1, \mathrm{v} / \mathrm{v})$ (Roller et al., 1994) was more effective (Fig. $2 \mathrm{~b})$ than the addition of formaldehyde (DeLong et al., 1989) or glutaraldehyde (Amann et al., 1990b) as fixative. However, after fixation with $50 \%$ ethanol, many of our nocardioform actinomycete reference strains still showed little or no fluorescent staining (data not shown). Whereas additional pre-treatment of the ethanol-fixed cells with lysozyme (Beimfohr et al., 1993) led to lysis of many nocardioform actinomycetes, a short incubation with mutanolysin (Assaf \& Dick, 1993) further improved probe accessibility to most reference strains while preserving morphological integrity (Table 1). It should be noted that this treatment did not permeabilize members of the genus Mycobacterium for in situ hybridization (Table 1) and completely lysed almost all of the Gram-negative bacteria strains analysed (data not shown). Extension of mutanolysin incubation times to $>10$ min was not found to be suitable for in situ hybridization as it increased the number of damaged nocardioform target cells. Treatment of ethanol-fixed nocardioform actinomycetes with organic solvents (acetone, chloroform, diethyl ether, $n$-hexane, methanol and toluol, and combinations of these solvents) was in general found to be ineffective in further permeabilizing nocardioform cell walls for in situ hybridization.

\section{In situ identification of nocardioform actinomycetes in activated sludge from the Berlin-Marienfelde sewage treatment plant}

In situ hybridization using the nocardioform-specific oligonucleotide probe MNP1 (Fig. 1) was performed to identify populations of nocardioform actinomycetes in the activated sludge from the Berlin-Marienfelde sewage 

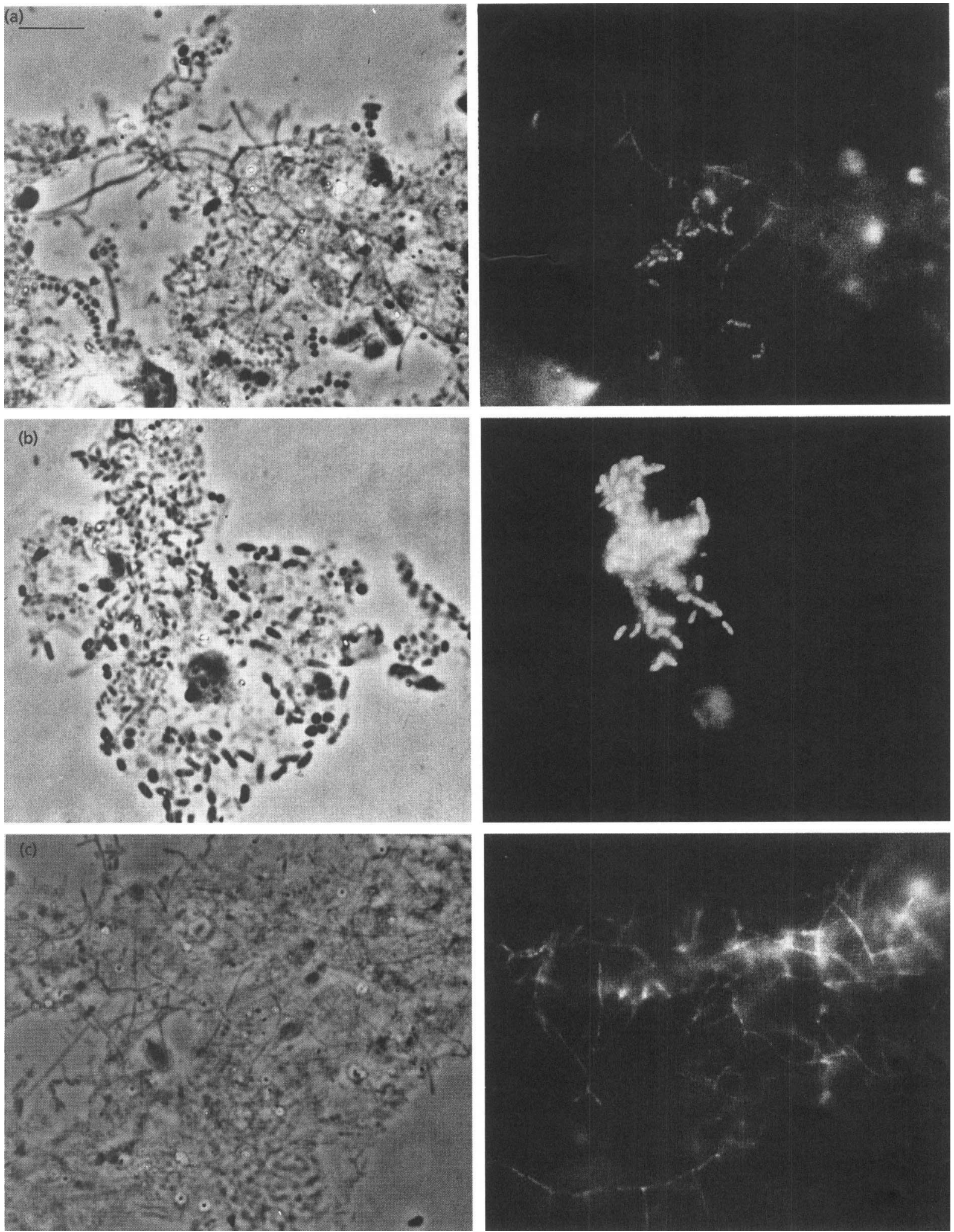

Fig. 3. Whole-cell hybridization of nocardioform actinomycetes in an activated-sludge sample from the BerlinMarienfelde wastewater treatment plant. For each panel, identical fields were viewed by phase-contrast microscopy (left) and epifluorescence microscopy (right). Bar, $10 \mu \mathrm{m}$. (a) In situ identification of nocardioform bacteria with fluoresceinlabelled probe MNP1. (b) In situ identification of short rod-shaped nocardioform actinomycetes with tetramethylrhodamine-labelled probe DLP. (c) In situ identification of typical branched filaments of nocardioform actinomycetes with tetramethylrhodamine-labelled probe GLP2. 
Nocardioform actinomycetes in activated sludge

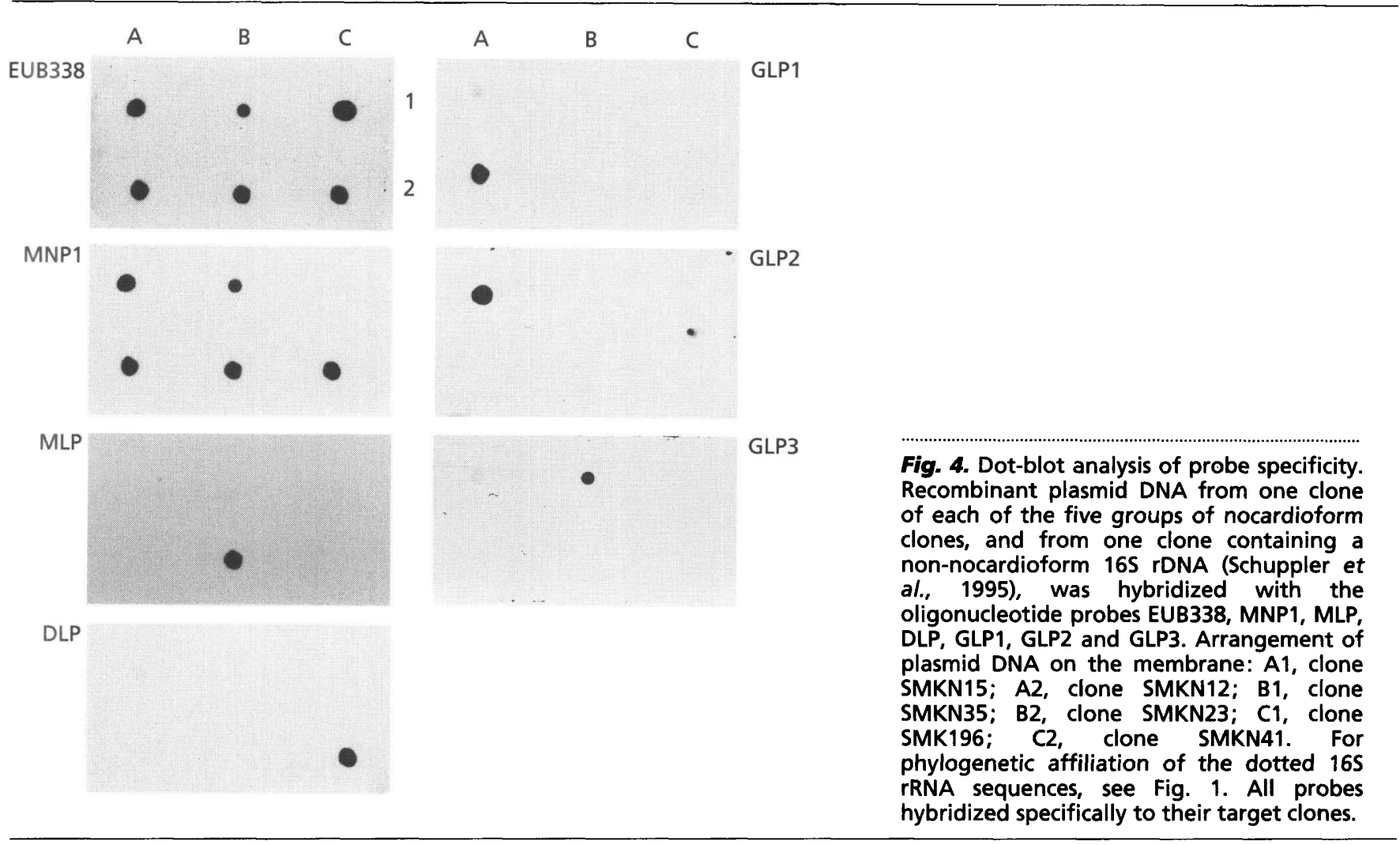

treatment plant. For this experiment, we used fixed material from the identical sludge sample which had been used in a previously described molecular characterization of nocardioform actinomycetes by $16 \mathrm{~S}$ rRNA analysis (Schuppler et al., 1995). In situ hybridization with probe MNP1 resulted in the detection of two populations with different morphologies. One morphotype represented typical branched filaments of nocardioform actinomycetes, whereas the other morphotype comprised short irregular rods (Fig. 3a). Both populations simultaneously hybridized with probe HGC69a (Roller et al., 1994), confirming that the bacteria belong to the group of actinomycetes and their relatives (data not shown).

Specificities of probes MLP, DLP, GLP1, GLP2 and GLP3 (Fig. 1) derived from nocardioform-actinomyceteaffiliated sequences described by Schuppler et al. (1995) were tested by dot-blot hybridization (Fig. 4). While the eubacteria-specific probe EUB338 hybridized to all of the plasmid DNA preparations tested, probe MNP1 bound exclusively to plasmid DNA from clones containing nocardioform 16S rDNA, confirming the specificity of probe MNP1. As expected, the five specific oligonucleotide probes MLP, DLP, GLP1, GLP2 and GLP3 hybridized exclusively to their respective target $16 \mathrm{~S}$ rDNA.

The application of these specific probes for in situ hybridization of activated sludge from Berlin-Marienfelde enabled a further discrimination of the different populations of nocardioform actinomycetes detected by probe MNP1. Whereas probe DLP specifically detected the short irregular rods, probe GLP2 identified the branched filaments in the activated sludge (Fig. 3). All bacteria identified with either probe DLP or probe GLP2 were simultaneously detectable in situ with probe MNP1. According to a recent database check using the ARB program package, all but one non-target bacteria for probes DLP and GLP2, which possess the target region of probe $\mathrm{MNP1}$, have at least two mismatches to the respective probe target regions demonstrating the desired probe specificities (Table 4). Although Dietzia maris has only one mismatch to the target region of probe DLP, whole-cell hybridization experiments demonstrated that it is not detected by probe DLP under stringent hybridization conditions (data not shown).

In spite of the fact that all probes were designed on the basis of nocardioform sequences from the previously described clone library (Schuppler et al., 1995), probes MLP, GLP1 and GLP3 failed to detect bacterial populations in the activated-sludge sample from the BerlinMarienfelde sewage treatment plant.

\section{In situ detection of nocardioform actinomycetes in activated sludge from different wastewater treatment plants}

To address the question of whether distinct populations of nocardioform actinomycetes in the Berlin-Marienfelde wastewater treatment plant are characteristic for plants removing phosphorus biologically (EBPR plants), fixed activated sludge from plants with and without EBPR (Table 2) was analysed. Initially, all sludge samples were simultaneously hybridized with probes 
Table 4. Difference alignment of the $16 \mathrm{~S}$ rRNA target regions of probes DLP and GLP2

\begin{tabular}{|c|c|c|}
\hline Organism & Target sequence of probe DLP & $\begin{array}{c}\text { Target region of } \\
\text { probe } \mathrm{MNP}{ }^{*}\end{array}$ \\
\hline & UGAGCUCCUGCCGCAUGGUGG & \\
\hline Brachybacterium faecium & $------\mathrm{U}--------------$ & - \\
\hline Dietzia maris & $---\mathrm{A}-----------------$ & + \\
\hline Mycobacterium chitae & G--------- U--------- & - \\
\hline Propionibacterium acnes & 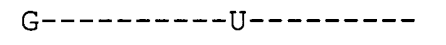 & - \\
\hline Rhodococcus equi & $----------\mathrm{U}-------\mathrm{C}--$ & + \\
\hline \multirow[t]{2}{*}{ Organism } & Target sequence of probe GLP2 & $\begin{array}{c}\text { Target region of } \\
\text { probe } M N P 1^{*}\end{array}$ \\
\hline & ACCGGAUAUGACCUGCCCUU & \\
\hline Gordona amarae & $---------------U \mathrm{U}-\mathrm{C}-$ & + \\
\hline Nocardia carnea & 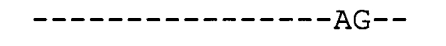 & + \\
\hline Rathayibacter rathayi & $------------------\mathrm{CG}$ & - \\
\hline
\end{tabular}

* See also Table 1.

MNP1 and HGC69a. In all samples, cells detectable with probe MNP1 were also identified with probe HGC69a, confirming that they were members of the group of Gram-positive bacteria with a high DNA $\mathrm{G}+\mathrm{C}$ content.

Sludge samples containing nocardioform populations detected by probe MNP1 were further analysed by hybridization with the specific probes DLP, GLP1, GLP2, GLP3 and MLP (Table 3). These specific probes were always applied simultaneously with probe MNP1. In 13 of the 16 analysed sludge samples, probe DLP identified short irregular rods morphologically identical to those detected in the Berlin-Marienfelde wastewater treatment plant (Fig. 5a, b). These bacteria, which also hybridized with probe MNP1, were particularly abundant in activated sludge obtained from the Hirblingen and Aldersbach plants. In samples from Aretsried, Darmstadt and Waßmannsdorf, we found branched filaments of nocardioform actinomycetes which bound probe GLP2 and probe MNP1. Corresponding to the results from Berlin-Marienfelde, no bacteria were detected with the specific probes MLP, GLP1 and GLP3 in all sludge samples analysed.

\section{In situ analysis of nocardioform actinomycetes by CLSM}

The use of CLSM enabled improved detection of bacteria inside sludge flocs by eliminating unfocused fluorescence. In addition, digital contrast enhancement and elimination of sections without information facilitated visualization of bacteria that gave only weak signals inside the sludge flocs (Fig. 5b, c). However, not all nocardioform bacteria detectable by phase-contrast gave bright signals after in situ hybridization. It was often observed that filamentous bacteria showed an irregular distribution of fluorescence over the filaments (Fig. 5c).

\section{DISCUSSION}

In situ hybridization with fluorescent rRNA-targeted oligonucleotide probes represents the most powerful technique for the direct in situ identification of single bacterial cells in complex microbial ecosystems. The application of in situ hybridization has enabled investigation of the structure and dynamics of microbial communities in activated sludge (e.g. Wagner et al., 1993; Manz et al., 1994; Wagner et al., 1994b, c, 1995; Mobarry et al., 1996; De Los Reyes et al., 1997).

On the basis of new nocardioform 16S rRNA sequences described by Schuppler et al. (1995), we designed specific oligonucleotide probes to identify the respective bacteria in activated sludge. In situ hybridization with probes DLP and GLP2 allowed the assignment of the two nocardioform populations that were initially detected by probe MNP1 to the respective sequence clusters of the comparative $16 \mathrm{~S}$ rRNA analysis. Probe DLP was designed on the basis of clone sequences SMKN6 and SMKN41 (Schuppler et al., 1995). The high degree of sequence similarity to $16 \mathrm{~S}$ rDNA of $D$. maris (Rainey et al., 1995a, b) suggested that the short irregular rods are closely related to this species originally isolated from soil (Nesterenko et al., 1982). Probe GLP2 is derived from clone sequences SMKN15 and SMKN29 (Schuppler et al., 1995), indicating that the bacteria identified by this probe represent close relatives of $G$. amarae (Blackall et al., 1994b; Ruimy et al., 1994), a species frequently found in activated sludge (Lechevalier \& Lechevalier, 1974). The in situ identification of these bacteria in activated sludge by FISH closed the gap to a 'full cycle rRNA analysis' (Amann et al., 1995). Unfortunately, the destructive effect of the mutanolysin treatment for most of the Gram-negative bacteria tested made it impossible to determine precisely the relative proportion of in situ identified nocardioform actinomycetes. 

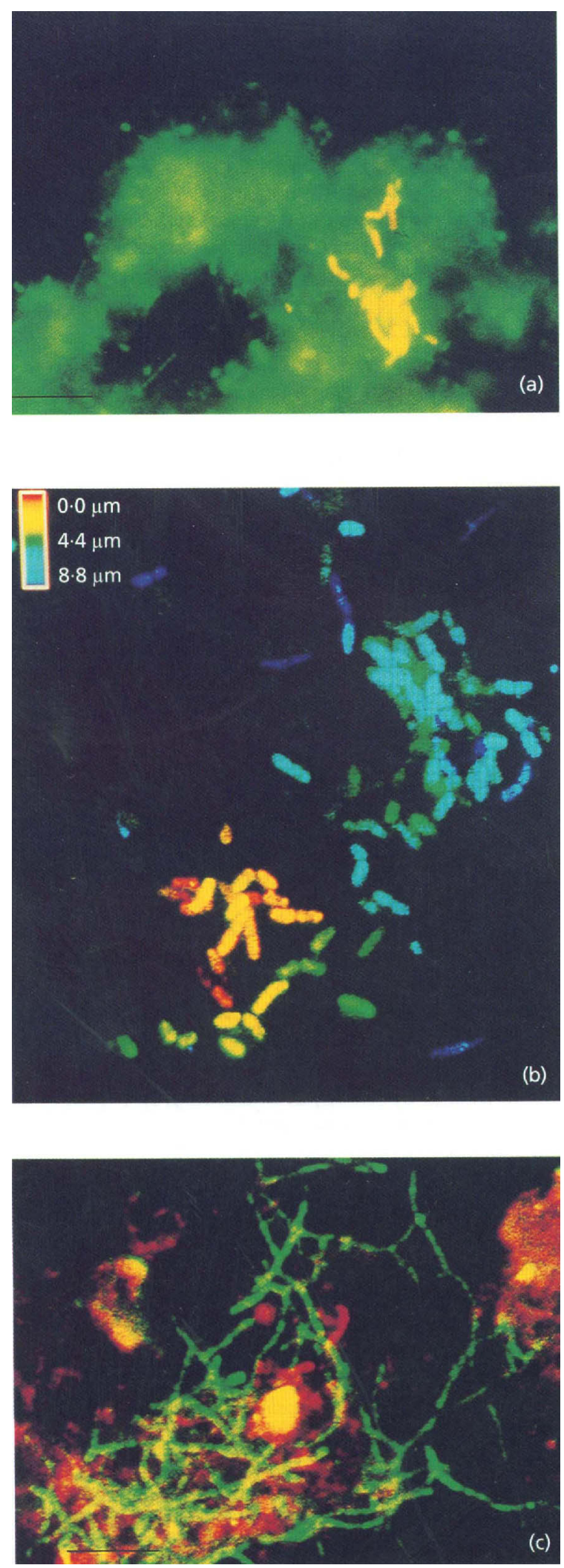

Fig. 5. (a) Simultaneous in situ hybridization of activatedsludge samples obtained from the wastewater treatment plant Essen-Werden with fluorescein-labelled probe EUB338 and tetramethylrhodamine-labelled probe DLP. Bar, $10 \mu \mathrm{m}$. High
The observation that no bacteria were detected with probes MLP, GLP1 and GLP3 in the activated-sludge material could be due to several reasons. Firstly, the cloned 16S rDNA which was used to design these probes could have originated from free DNA or DNA from dead cells. Secondly, the fixation and hybridization conditions used in this study were not suitable for all species of nocardioform actinomycetes (Table 1). The cell walls of Mycobacterium species contain mycolic acids with extremely long aliphatic chains and are consequently not permeable to the fluorescently labelled probes, even after treatment with mutanolysin. As the target 16S rDNA sequences for probe MLP (SMKN22 and SMKN23) are highly similar to those of the genus Mycobacterium (Fig. 1), it is not surprising that no target bacteria for probe MLP were detectable by in situ hybridization.

The target molecule for the fluorescent oligonucleotide probes is rRNA. Consequently, an insufficient number of ribosomes per cell due to reduced metabolic activity could be another reason for the failure of in situ detection with probes MLP, GLP1 and GLP3. Wagner $e t$ al. (1993) found that members of the family Enterobacteriaceae were not detectable by in situ hybridization if the activated sludge was fixed immediately after sampling. However, if the sludge sample was incubated with nutrients prior to fixation, the respective bacteria gave bright signals. In addition, the three-dimensional arrangement of the rRNA molecule results in blockage of specific regions for in situ hybridization, preventing the detection of bacteria even though they possess a sufficient number of ribosomes and show good permeability for oligonucleotide probes (Amann et al., 1995).

The investigation of various wastewater treatment plants by in situ hybridization of activated-sludge samples with oligonucleotide probe MNP1 indicated that nocardioform actinomycetes are widely distributed. Populations of nocardioform actinomycetes were detected in nearly all plants investigated, an observation which correlates with the results of Bark et al. (1993). Hybridization with probe DLP showed a widespread occurrence of short irregular rods, sometimes in very high numbers, in activated sludge. This observation suggests that these bacteria play an important role in the

background fluorescence obtained with the bacterial probe is mainly caused by Gram-negative cell lysis due to the fixation and pre-treatment procedures applied. (b) CLSM analysis of in situ hybridization preparations from ethanol/PBS-fixed activated sludge from the Hirblingen wastewater treatment plant with tetramethylrhodamine-labelled probe DLP. The depth profile shows the three-dimensional location of the bacteria indicated by different colours. (c) CLSM analysis of in situ hybridization preparations from ethanol/PBS-fixed activated sludge from the Berlin-Marienfelde wastewater treatment plant with fluorescein-labelled probe MNP1. Bar, $10 \mu \mathrm{m}$ (also applies to b). Autofluorescence of the activatedsludge preparations was minimized by selecting suitable optical sections and digital contrast enhancement procedures. 
wastewater treatment process. However, their detection in high numbers in wastewater treatment plants both with (e.g. Hirblingen) and without (e.g. Aldersbach) EBPR does not enable any conclusions on their possible role in the biological removal of phosphorus.

In contrast to the short irregular rods, the typically branched filaments of nocardioform actinomycetes identified in situ by probe GLP2 were found only occasionally. Some sewage treatment plants contained filamentous forms of nocardioform actinomycetes which were not identified by probe GLP2, suggesting the existence of different populations of bacteria that share the same gross morphology. Interestingly, most sludge samples that contained populations of branched filaments were derived from wastewater treatment plants with EBPR (Berlin-Marienfelde, Darmstadt, EssenWerden, Waßmannsdorf). It is well-established that filamentous forms of nocardioform actinomycetes $a b-$ sorb and store polyphosphates (Schön, 1994) and since plants of the EBPR type are particularly prone to foaming problems, it could be proposed that branched filamentous forms of nocardioform actinomycetes are involved in both processes, i.e. EBPR and sludge foaming. This hypothesis is also supported by recent findings that high $\mathrm{G}+\mathrm{C}$ Gram-positive bacteria represent an important, polyphosphate-accumulating part of the microbial community in EBPR plants which increases in number after anaerobic acetate dosage (Wagner et al., 1994a).

In this study, the use of CLSM enabled improved detection of nocardioform actinomycetes in activated sludge by in situ hybridization with fluorescently labelled oligonucleotide probes, even inside sludge flocs. Investigation of their spatial distribution showed that physiologically active bacteria (indicated by a high cellular rRNA content) were not restricted to the outer area of sludge flocs. This suggests that bacteria inside the sludge flocs are provided with sufficient nutrients for activity.

In situ hybridization of Gram-positive filamentous bacteria often resulted in an irregular distribution of fluorescence signals over the whole filaments. While some parts gave bright signals, other parts of the same filament exhibited no fluorescence. The borderlines of single cells in the filaments are invisible. Consequently, it remains unresolved whether different parts of the filaments belong to the same cell or not. A possible explanation for the staining pattern observed would be that parts showing no signals represent dead cells or at least cells with a low metabolic activity. Variations in permeability of the cell envelope within the filament is another possible explanation of this phenomenon.

\section{ACKNOWLEDGEMENTS}

This work was supported in part by a grant from the state of Baden-Württemberg (LGFG). We thank Peter Hutzler (GSFForschungszentrum für Umwelt und Gesundheit, Institut Pathologie und biomedizinische Bildanalyse, Oberschleissheim, Germany) for access to the confocal laser scanning microscope.

\section{REFERENCES}

Amann, R. I., Krumholz, L. \& Stahl, D. A. (1990a). Fluorescentoligonucleotide probing of whole cells for determinative, phylogenetic and environmental studies in microbiology. J Bacteriol 172, 762-770.

Amann, R. I., Binder, B. J., Olson, R. J., Chisholm, S. W., Devereux, R. \& Stahl, D. A. (1990b). Combination of $16 \mathrm{~S}$ rRNA-targeted oligonucleotide probes with flow cytometry for analyzing mixed microbial populations. Appl Environ Microbiol 56, 1919-1925.

Amann, R., Ludwig, W. \& Schleifer, K. H. (1995). Phylogenetic identification and in situ detection of individual microbial cells without cultivation. Microbiol Rev 59, 143-169.

Assaf, N. A. \& Dick, W. A. (1993). Spheroplast formation and plasmid isolation from Rhodococcus spp. BioTechniques 15, 1010-1015.

Bark, K., Kămpfer, P., Sponner, A. \& Dott, W. (1993). Polyphosphate-dependent enzymes in some coryneform bacteria isolated from activated sludge. FEMS Microbiol Lett 107, 133-138.

Beimfohr, C., Krause, A., Amann, R., Ludwig, W. \& Schleifer, K. H. (1993). In situ identification of Lactococci, Enterococci and Streptococci. Syst Appl Microbiol 16, 450-456.

Blackall, L. L., Harbers, A. E., Greenfield, P. F. \& Hayward, A. C. (1988). Actinomycete scum problems in Australian activated sludge plants. Water Sci Technol 20, 23-29.

Blackall, L. L., Harbers, A. E., Greenfield, P. F. \& Hayward, A. C. (1991). Foaming in activated sludge plants: a survey in Queensland, Australia and an evaluation of some control strategies. Water Res 25, 313-317.

Blackall, L. L., Seviour, E. M., Cunningham, M. A., Seviour, R. J. \& Hugenholtz, P. (1994a). 'Microthrix parvicella' is a novel, deep branching member of the actinomycetes subphylum. Syst Appl Microbiol 17, 513-518.

Blackall, L. L., Barker, S. C. \& Hugenholtz, P. (1994b). Phylogenetic analysis and taxonomic history of Nocardia pinensis and Nocardia amarae. Syst Appl Microbiol 17, 513-518.

Blackbeard, J. R., Ekama, G. A. \& Marais, G. V. R. (1986). A survey of filamentous bulking and foaming in activated sludge plants in South Africa. Water Pollut Control 85, 90-100.

Brosius, J., Dull, T. L., Sleeter, D. D. \& Noller, H. F. (1981). Gene organization and primary structure of a ribosomal RNA operon from Escherichia coli. J Mol Biol 148, 107-127.

DeLong, E. F., Wickham, G. S. \& Pace, N. R. (1989). Phylogenetic stains: ribosomal RNA-based probes for the identification of single cells. Science 243, 1360-1363.

De Los Reyes, F. L., Ritter, W. \& Raskin, L. (1997). Group-specific small subunit rRNA hybridization probes to characterize filamentous foaming in activated sludge systems. Appl Environ Microbiol 63, 1107-1117.

Foot, R. J., Kocianova, E. \& Forster, C. F. (1992). Variable morphology of Microthrix parvicella in activated sludge systems. Water Res 26, 875-880.

Hahn, D., Amann, R., Ludwig, W., Akkermans, A. D. L. \& Schleifer, K. H. (1992). Detection of micro-organisms in soil after in situ hybridization with rRNA-targeted, fluorescently labelled oligonucleotides. J Gen Microbiol 138, 879-887.

Lechevalier, H. A. (1989). Nocardioform actinomycetes. In Bergey's Manual of Systematic Bacteriology, vol. 4, pp. 2348-2404. Edited by S. T. Williams, M. E. Sharpe \& J. G. Holt. Baltimore: Williams \& Wilkins.

Lechevalier, H. A., Lechevalier, M. P., Wyszkowski, P. E. \& Mariat, F. (1976). Actinomycetes found in sewage-treatment plants of the 
activated sludge type. In Actinomycetes: the Boundary Microorganisms, pp. 227-247. Edited by T. Arai. Tokyo \& Singapore: Toppan.

Lechevalier, M. P. \& Lechevalier, H. A. (1974). Nocardia amarae sp. nov., an actinomycete common in foaming activated sludge. Int J Syst Bacteriol 24, 278-288.

Lemmer, H. \& Kroppenstedt, R. M. (1984). Chemotaxonomy and physiology of some actinomycetes isolated from scumming activated sludge. Syst Appl Microbiol 5, 124-135.

Macnaughton, S. J., O'Donnell, A. G. \& Embley, T. M. (1994). Permeabilization of mycolic-acid-containing actinomycetes for in situ hybridization with fluorescently labelled oligonucleotide probes. Microbiology 140, 2859-2865.

Manz, W., Amann, R., Ludwig, W., Wagner, M. \& Schleifer, K. H. (1992). Phylogenetic oligodeoxynucleotide probes for the major subclass of proteobacteria: problems and solutions. Syst Appl Microbiol 15, 593-600.

Manz, W., Wagner, M., Amann, R. \& Schleifer, K. H. (1994). In situ characterization of the microbial consortia active in two wastewater treatment plants. Water Res 28, 1715-1723.

Mobarry, B. K., Wagner, M., Urbain, V., Rittmann, B. \& Stahl, D. A. (1996). Phylogenetic probes for analyzing abundance and spatial organization of nitrifying bacteria. Appl Environ Microbiol 62, 2156-2162.

Nesterenko, O. A., Nogina, T. M., Kasumova, S. A., Kvasnikov, E. I. \& Batrakov, S. G. (1982). Rhodococcus luteus nom. nov. and Rhodococcus maris nom. nov. Int J Syst Bacteriol 32, 1-14.

Olsen, G. J., Lane, D. J., Giovannoni, S. J., Pace, N. R. \& Stahl, D. A. (1986). Microbial ecology and evolution: a ribosomal RNA approach. Annu Rev Microbiol 40, 337-365.

Rainey, F. A., Burghardt, J., Kroppenstedt, R. M., Klatte, S. \& Stackebrandt, E. (1995a). Phylogenetic analysis of the genera $R$ bodococcus and Nocardia and evidence for the evolutionary origin of the genus Nocardia from within the radiation of Rhodococcus species. Microbiology 141, 523-528.

Rainey, F. A., Klatte, S., Kroppenstedt, R. M. \& Stackebrandt, E. (1995b). Dietzia, a new genus including Dietzia maris comb. nov., formerly Rhodococcus maris. Int J Syst Bacteriol 45, 32-36.

Roller, C., Wagner, M., Amann, R., Ludwig, W. \& Schleifer, K. H. (1994). In situ probing of Gram-positive bacteria with high DNA $\mathrm{G}+\mathrm{C}$ content using $23 \mathrm{~S}$ rRNA-targeted oligonucleotides. Microbiology 140, 2849-2858.
Ruimy, R., Boiron, P., Boivin, V. \& Christen, R. (1994). A phylogeny of the genus Nocardia deduced from the analysis of small-subunit ribosomal DNA sequences, including transfer of Nocardia amarae to the genus Gordona as Gordona amarae com. nov. FEMS Microbiol Lett 123, 261-268.

Schön, G. (1994). Biological phosphorus elimination in the activated sludge process for the treatment of wastewater. Bioengineering 4, 23-32.

Schuppler, M., Mertens, F., Schön, G. \& Göbel, U. B. (1995). Molecular characterization of nocardioform actinomycetes in activated sludge by $16 \mathrm{~S}$ rRNA analysis. Microbiology 141, 513-521.

Soddell, J. A. \& Seviour, R. J. (1990). Microbiology of foaming in activated sludge plants. J Appl Bacteriol 69, 145-176.

Stahl, D. A. \& Amann, R. (1991). Development and application of nucleic acid probes in bacterial systematics. In Sequencing and Hybridization Techniques in Bacterial Systematics, pp. 205-248. Edited by E. Stackebrandt \& M. Goodfellow. Chichester: Wiley.

Wagner, M., Amann, R., Lemmer, H. \& Schleifer, K. H. (1993). Probing activated sludge with proteobacteria-specific oligonucleotides: inadequacy of culture-dependent methods for describing microbial community structure. Appl Environ Microbiol 59, 1520-1525.

Wagner, M., Amann, R., Lemmer, H., Manz, W. \& Schleifer, K. H. (1994a). Probing activated sludge with fluorescently labeled rRNA-targeted oligonucleotides. Water Sci Technol 29, 15-23.

Wagner, M., Amann, R., Kämpfer, P., Assmus, B., Hartmann, A., Hutzler, P., Springer, N. \& Schleifer, K. H. (1994b). Identification and in situ detection of gram-negative filamentous bacteria in activated sludge. Syst Appl Microbiol 17, 405-417.

Wagner, M., ABmus, B., Hartmann, A., Hutzler, P. \& Amann, R. (1994c). In situ analysis of microbial consortia in activated sludge using fluorescently labeled, rRNA-targeted oligonucleotide probes and confocal scanning laser microscopy. J Microsc 176, 181-187.

Wagner, M., Rath, G., Amann, R., Koops, H.-P. \& Schleifer, K. H. (1995). In situ identification of ammonia-oxidizing bacteria. Syst Appl Microbiol 18, 251-264.

Received 2 April 1997; revised 25 August 1997; accepted 12 September 1997. 